\title{
Enhanced total nitrogen removal performance in a modified Orbal oxidation ditch system with internal nitrate recycle
}

\author{
Xin Zhou ${ }^{\mathrm{a}, *}$, Yunping Han ${ }^{\mathrm{b}}$, Xuesong Guo ${ }^{\mathrm{b}}$ \\ ${ }^{a}$ College of Environmental Science and Engineering, Taiyuan University of Technology, Taiyuan 030024, China \\ ${ }^{\mathrm{b}}$ Research Center for Eco-Environmental Sciences, Chinese Academy of Sciences, Beijing 100085, China
}

\section{H I G H L I G H T S}

- An Orbal oxidation ditch with nitrate recycle for enhanced TN removal was developed.

- The optimal DO for SND was 0.15-0.25 mg/L.

- The highest TN removal was achieved at internal recycle ratio of 9.4.

- Nitrogen mass balances confirmed SND coupled with pre-denitrification.

- Nitrogen removal was closely related to bacterial community composition.

\section{A R T I C L E I N F O}

\section{Article history:}

Received 14 November 2012

Received in revised form 25 April 2013

Accepted 27 April 2013

Available online 7 May 2013

\section{Keywords:}

Orbal oxidation ditch

Nitrogen removal

Internal nitrate recycle

Aerated-anoxic

Pre-denitrification

\begin{abstract}
A B S T R A C T
A pilot-scale modified Orbal oxidation ditch with internal recycle of the nitrified liquor was developed to significantly enhance total nitrogen (TN) removal through simultaneous nitrification/denitrification (SND) coupled with pre-denitrification under the aerated-anoxic condition. Long-term operational results showed that the highest TN removal efficiency was achieved at very low dissolved oxygen (DO) of $0.15-0.25 \mathrm{mg} / \mathrm{L}$ and oxidation-reduction potential (ORP) of $10-40 \mathrm{mv}$ within the outer channel. Appropriate internal recycle ratio played a significant role for increasing nitrates reduction within the outer channel, however, excessively high recycle flow deteriorated nitrogen removal instead because of diluted carbon source. At recycle ratio of 9.4, TN removal efficiency further increased to about $87 \%$ at optimal DO and pre-denitrification was responsible for TN removal improvement according to nitrogen mass balances. Molecular biology analysis revealed the correlation between variations in nitrogen removal and changes in bacterial community composition.
\end{abstract}

(c) 2013 Elsevier B.V. All rights reserved.

\section{Introduction}

The oxidation ditch, as a modified activated sludge process, is typically a complete-mix closed-loop bioreactor in which surface aerators provide circulation, mixing and aeration of the mixed liquor. Oxidation ditches have been widely applied in small- to medium-sized municipal wastewater treatment plants (WWTPs) throughout the world [1] mainly due to their abilities to achieve organic removal, almost complete nitrification and partial denitrification with low operational requirements and operation and maintenance costs [2-4]. One of the most commonly used oxidation ditch type is the Orbal process system generally consisting of three concentric round or elliptic channels, originally developed in South Africa in 1970s [5]. Nowadays, more than 500 Orbal oxidation ditches have been used for the domestic wastewater treatment in

\footnotetext{
* Corresponding author. Tel./fax: +86 3516079557.

E-mail address: zhouxin@tyut.edu.cn (X. Zhou).
}

North America, Europe, Africa as well as Asia. In China, dozens of Orbal process plants have been put into operation until recently.

Unlike other biological nitrogen removal processes, the mechanism of removing nitrogen in a conventional oxidation ditch is based on both nitrification and denitrification simultaneously occurred due to the alternation of aerobic and anoxic zones along the single aerobic channel $[2,3,6]$. But in a multi-channel Orbal system, 0-1-2 mg/L dissolved oxygen (DO) profiles are typically created from the outer to inner channel by independently controlling aeration input for each channel [7-9]. The amount of oxygen in the outer channel is usually lower than the oxygen demand for promoting simultaneous nitrification and denitrification (SND) under aerated-anoxic conditions with oxygen deficit $[10,11]$, while the amount of oxygen within the middle and inner channels is higher than the oxygen demand for removing remaining organic matters and ammonia [10]. Due to stratified oxygen levels not only within the each single channel but also across three different channels, nitrogen removal efficiencies in the multi-channel systems 
are much higher and more stable than those in the single-channel systems.

Nitrogen removal performance in the Orbal system is mainly influenced by SND depending on dynamic balance between nitrification and denitrification rates in the outer channel, which is greatly affected by DO $[12,13]$. However, since DO concentration for optimal SND is generally within a rather narrow range $[9,14-$ 16] due to their conflicts of oxygen and organic substrate requirements between nitrification and denitrification [16-18], the balance is unsteadily maintained unless DO can be accurately controlled. Actually, in some practical Orbal oxidation ditches, either partial nitrification owing to insufficient oxygen or reduced denitrification induced by excess oxygen takes place in the first channel while only nitrification is accomplished under high oxygen conditions in the remaining two channels, thus steadily satisfactory TN removal performances via SND solely are not always achieved as expected $[9,19,20]$. The addition of mixed liquor recycle from aerobic channels to aerated-anoxic channel, similar with anoxic/oxic (A/O) process, seems to be a feasible alternative for enhancing denitrification efficiency $[7,10]$ if SND fails in Orbal processes [19]. Nevertheless, high recycle flow required for effective pre-denitrification [21] would inevitably deteriorate denitrification due to considerable oxygen brought from the aerated channels to anoxic channel [22] and increase energy consumption for internal recirculation. Hence, TN removal efficiency is hard to be further improved in Orbal ditches at such low recycle ratios.

Therefore, a modified pilot-scale Orbal oxidation ditch integrated with internal recycle of the nitrified liquor was developed to considerably enhance TN removal performance under the aerated-anoxic condition. The objectives of this study were firstly to investigate the effect of DO on SND performance to optimize TN removal within the outer channel of aerated-anoxic oxidation ditch and then determine the optimal internal recycle ratio for enhanced pre-denitrification at the optimum DO within the outer channel of the modified oxidation ditch. Furthermore, dynamic variations in bacterial community structure closely related with nitrogen removal characteristics were analyzed by polymerase chain reaction-denaturing gradient gel electrophoresis (PCR-DGGE).

\section{Material and methods}

\subsection{System setup}

The experiment was conducted in a pilot-scale Orbal oxidation ditch operated for about two years (Fig. 1). Raw domestic wastewater via preliminary treatments such as bar screen and grit chamber was directly pumped into the wastewater tank, and the seed sludge was inoculated from a full-scale WWTP with Orbal process. The total working volume of oxidation ditch is $11.4 \mathrm{~m}^{3}$ with the size ratio of three channels of approximately 48\%:33\%:19\% (outer:middle:inner). Aeration supply and circulation of the mixed liquor within each channel were independently controlled through adjusting rotating speeds of brush aerator via frequency converters. To enhance pre-denitrification, internal recycle of nitrified mixed liquor from the middle channel into the outer channel was implemented in a modified oxidation ditch. A square hole with the size of about $20 \mathrm{~cm} \times 20 \mathrm{~cm}$ in the baffle wall between the outer and middle channels was located at one third of the ditch height below the water surface. One rotating door was fixed at the one side of the hole connected through a metal pole controlled by a steering wheel with scale. A certain amount of the mixed liquor

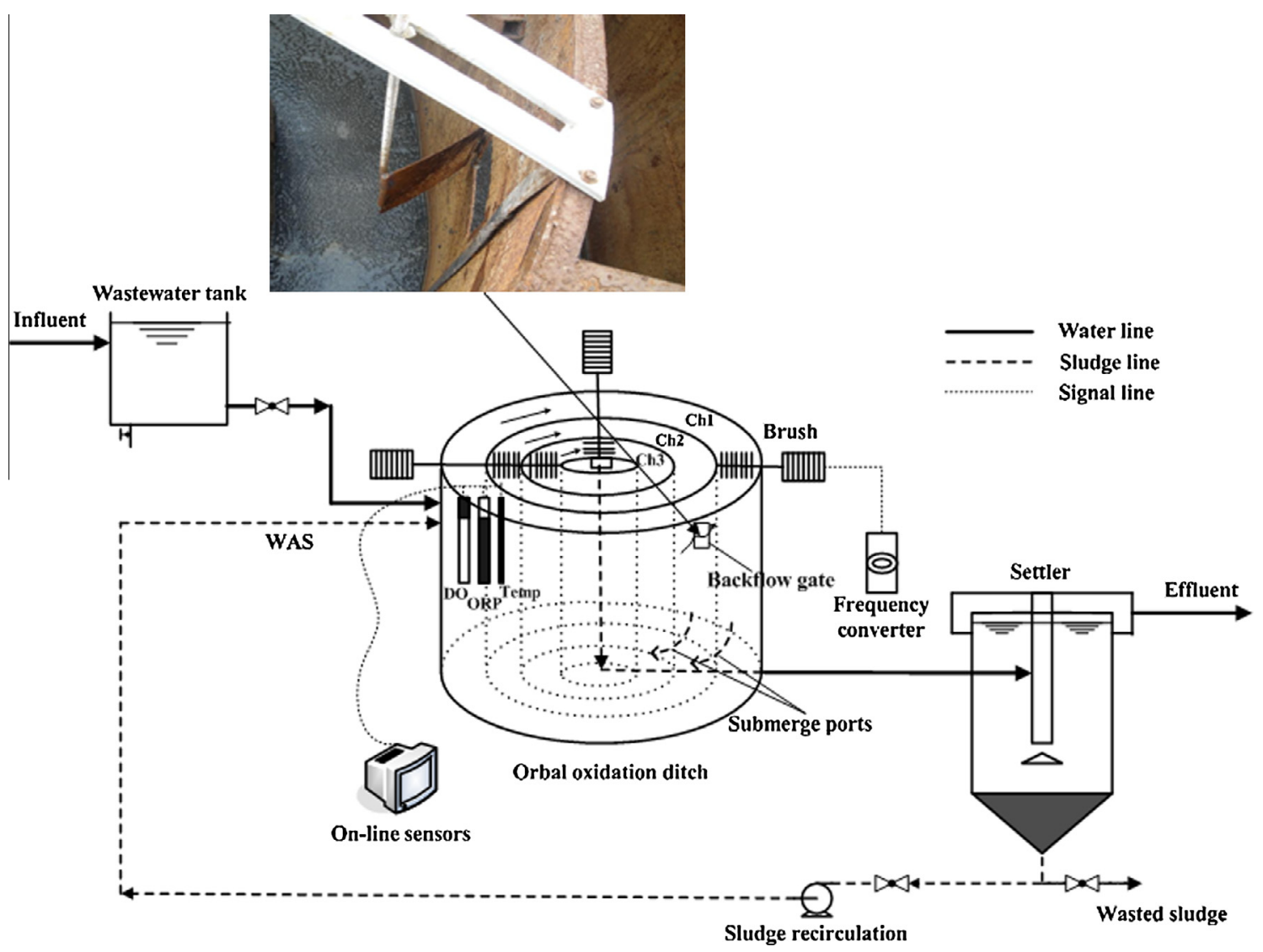

Fig. 1. Schematic diagram of a modified pilot-scale Orbal oxidation ditch. 
Table 1

Influent wastewater characteristics of the pilot-scale experiment.

\begin{tabular}{lcc}
\hline Parameter/Unit & Experiment 1 (114 days) & Experiment 2 (123 days) \\
\hline $\mathrm{pH}$ & $7.7 \pm 0.3^{\mathrm{a}}$ & $7.6 \pm 0.3$ \\
$\mathrm{~T}{ }^{\circ} \mathrm{C}$ & $24.0 \pm 3.5$ & $23.6 \pm 2.8$ \\
$\mathrm{COD} \mathrm{mg} / \mathrm{L}$ & $387 \pm 119$ & $363 \pm 95$ \\
$\mathrm{BOD}_{5} \mathrm{mg} / \mathrm{L}$ & $166 \pm 54$ & $158 \pm 46$ \\
$\mathrm{NH}_{4}^{+}-\mathrm{N} \mathrm{mg/L}$ & $47.3 \pm 5.9$ & $45.7 \pm 3.3$ \\
$\mathrm{NO}_{3}^{-}-\mathrm{N} \mathrm{mg/L}$ & $0.5 \pm 0.4$ & $1.0 \pm 0.5$ \\
$\mathrm{NO}_{2}^{-}-\mathrm{N} \mathrm{mg/L}$ & $0.02 \pm 0.02$ & $0.04 \pm 0.02$ \\
$\mathrm{TN} \mathrm{mg} / \mathrm{L}$ & $52.1 \pm 7.8$ & $58.5 \pm 3.6$ \\
$\mathrm{COD} / \mathrm{TKN}$ & $7.4 \pm 1.9$ & $6.7 \pm 1.4$ \\
\hline
\end{tabular}

a The values are the average \pm standard deviations.

from the middle channel easily controlled by adjusting opening angle of the gate could automatically run back into the outer channel for denitrification due to blocking of the gate without needing any pumping power. The on-line sensors of temperature, DO and ORP were positioned at $15 \mathrm{~cm}$ below the water surface at the fixed location of the outer channel.

\subsection{Experimental design and wastewater characteristics}

The whole pilot experiment mainly included two stages: Experiment 1: efficient TN removal via SND in the outer channel of the Orbal system through precise control of DO and ORP; Experiment 2: enhanced nitrogen removal in a modified Orbal oxidation ditch with internal recycle for pre-denitrification at the optimal DO for SND in Experiment 1. The characteristics of influent wastewater during two experimental stages were summarized in Table 1.

\subsection{Operational conditions}

Hydraulic residence time (HRT) of the Orbal oxidation ditch was about $18 \mathrm{~h}$, the mixed liquid suspended solids (MLSS) were $2800-3600 \mathrm{mg} / \mathrm{L}$, the returned sludge ratio was $100-120 \%$, and sludge residence time (SRT) was controlled at 20-30 days through discharging the amount of surplus sludge from the secondary settler in terms of the monitoring of MLSS concentrations from the oxidation ditch and the wasted sludge. The organic-loading rate and the nitrogen-loading rate were $0.065-$ $0.075 \mathrm{kgBOD}{ }_{5} / \mathrm{kgMLSS} \cdot \mathrm{d}$ and $0.019-0.031 \mathrm{kgTKN} / \mathrm{kgMLSS} \cdot \mathrm{d}$, respectively. The settling ability of the sludge throughout the experimental periods was generally better, with the sludge volume index (SVI) between 97 and 129 and the settling velocity (SV) of $35-40 \%$. Both experiments were operated at high and moderate temperatures among $20-27^{\circ} \mathrm{C}$ from May to September during two years. DO in the outer channel could be accurately adjusted for enhancing nitrogen removal while DO in the other two channels were kept among $0.7-1.2 \mathrm{mg} / \mathrm{L}$ and $1.7-2.5 \mathrm{mg} / \mathrm{L}$, respectively, without intentional oxygen control. The reactor system was operated at different DO concentrations (Experiment 1) and internal recycle ratios (Experiment 2) as listed in Tables 2 and 3.

Table 2

Operational conditions in Experiment 1.

\begin{tabular}{lllll}
\hline Operation conditions & Run 1 & Run 2 & Run 3 & Run 4 \\
\hline Time (days) & $0-28$ & $30-62$ & $64-90$ & $92-114$ \\
DO $(\mathrm{mg} / \mathrm{L})$ & $0.06 \pm 0.04$ & $0.20 \pm 0.07$ & $0.52 \pm 0.05$ & $0.36 \pm 0.06$ \\
ORP $(\mathrm{mV})$ & $-45 \pm 11$ & $26 \pm 12$ & $72 \pm 10$ & $53 \pm 13$ \\
\hline
\end{tabular}

Table 3

Operational conditions in Experiment 2 (at 0.15-0.25 mg/L DO).

\begin{tabular}{|c|c|c|c|c|c|}
\hline Operation conditions & Run 1 & Run 2 & Run 3 & Run 4 & Run 5 \\
\hline Time (days) & $0-20$ & $21-43$ & $44-74$ & $75-98$ & $99-123$ \\
\hline Opening angle $\left(^{\circ}\right)$ & 0 & 5 & 15 & 40 & 75 \\
\hline Average velocity $(\mathrm{m} / \mathrm{s})$ & 0 & 0.017 & 0.039 & 0.078 & 0.102 \\
\hline Returned flow $\left(\mathrm{m}^{3} / \mathrm{h}\right)$ & 0 & 2.448 & 5.616 & 11.232 & 14.688 \\
\hline Interal recycle ratio ${ }^{\mathrm{a}}(-)$ & 0 & 4.1 & 9.4 & 18.7 & 24.5 \\
\hline
\end{tabular}

a Interal recycle ratio $(R)$ : the average ratio between the mixed liquor interna recycle flow rate and the influent wastewater flow rate.

\subsection{Analytical methods}

\subsubsection{Chemical analysis}

COD was analyzed by a Multi-Function Reactor (DR2800, Euro Tech) and portable spectrophotometers (DR2800, Hach). BOD $\mathrm{NH}_{4}^{+}-\mathrm{N}, \mathrm{NO}_{3}^{-}-\mathrm{N}, \mathrm{NO}_{2}^{-}-\mathrm{N}, \mathrm{TN}, \mathrm{MLSS}$ and SVI were analyzed according to Standard Methods [23]. pH was measured with a probable pH meter (WTW Multi340i).Temperature, DO and ORP were realtimely monitored using on-line sensors (Hach $\mathrm{sc} 100^{\mathrm{TM}}$ controller).

\subsubsection{Calculation of SND efficiency}

Nitrification rate $\left(r_{\text {nitrification }}\right)$ and denitrification rate $\left(r_{\text {denitrifica- }}\right.$ tion) as well as the SND efficiency (SND\%) achieved in the outer channel were calculated according to formulas as below. $[13,24]$

$r_{\text {nitrification }}\left(\mathrm{mg} \mathrm{L}^{-1} \cdot \mathrm{h}^{-1} \mathrm{NH}_{4}^{+}\right)=\frac{\mathrm{NH}_{4 \text { in }}^{+}-\mathrm{NH}_{4}^{+} \text {out }}{\mathrm{HRT}_{\text {outer }}}$

$r_{\text {denitrification }}\left(\mathrm{mg} \mathrm{L}^{-1} \cdot \mathrm{h}^{-1} \mathrm{NO}_{x}^{-}\right)=\frac{\mathrm{NH}_{4}^{+} \text {in }-\mathrm{NH}_{4}^{+} \text {out }-\mathrm{NO}_{x \text { out }}^{-}}{\mathrm{HRT}_{\text {outer }}}$

$\mathrm{SND} \%=\frac{r_{\text {denitrification }}}{r_{\text {nitrification }}} \times 100 \%$

where $\mathrm{NH}_{4}^{+}-\mathrm{N}_{\text {in }}$ is the influent $\mathrm{NH}_{4}^{+}-\mathrm{N} ; \mathrm{NH}_{4}^{+}-\mathrm{N}_{\text {out }}$ is the effluent $\mathrm{NH}_{4}^{+}-\mathrm{N}_{\text {in }} ;\left(\mathrm{NH}_{4}^{+}-\mathrm{N}_{\text {in }}-\mathrm{NH}_{4}^{+}-\mathrm{N}_{\text {out }}\right)$ is $\mathrm{NO}_{x}^{-}$converted by nitrification; $\mathrm{NO}_{x}^{-}$out is the effluent $\mathrm{NO}_{x}^{-}$; $\mathrm{HRT}_{\text {outer }}$ is HRT in the outer channel.

\subsubsection{Measurement of internal recycle flow}

Internal recycle flowrate was estimated by cross-sectional area and average velocity based on nine measuring points located at three different heights of the recycle opening (see Fig. 2 and Table 3). Velocity was measured by FlowTracker Handheld-ADV (SonTek/YSI).

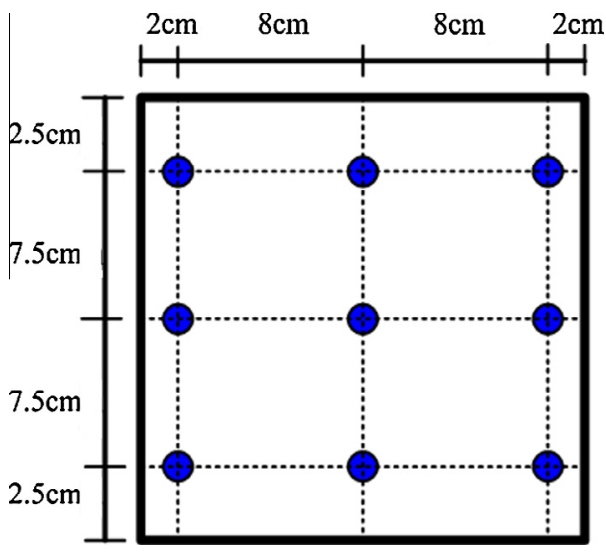

Fig. 2. Measuring points for velocity distributed in an internal recycle hole. 


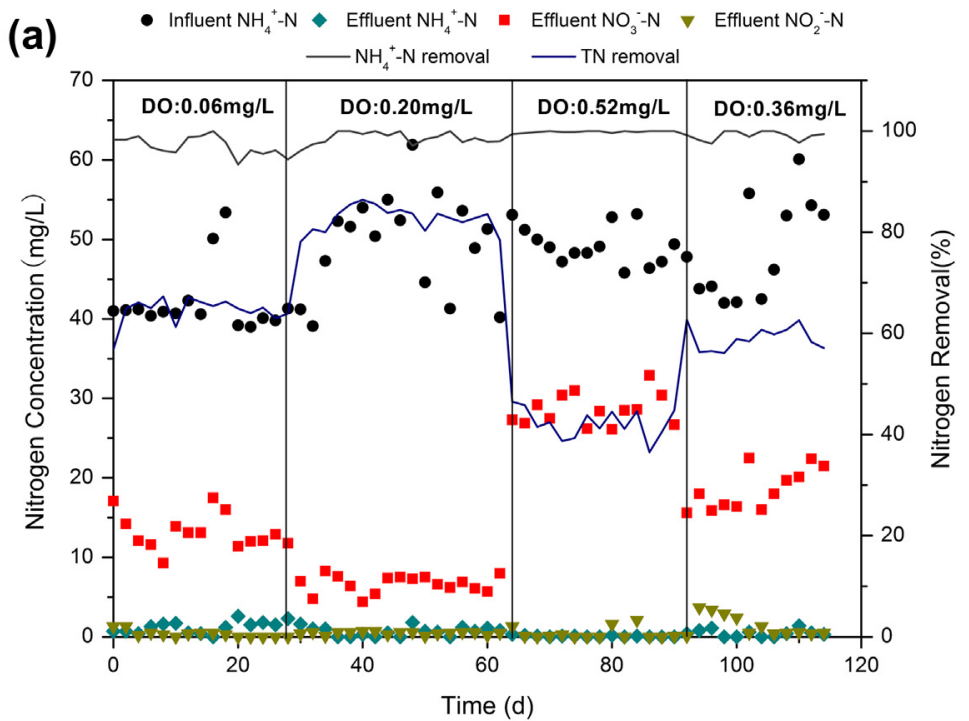

(b) $\square$ Ammonia Nitrogen $\quad \square$ Organic Nitrogen $\square$ Oxidized Nitrogen
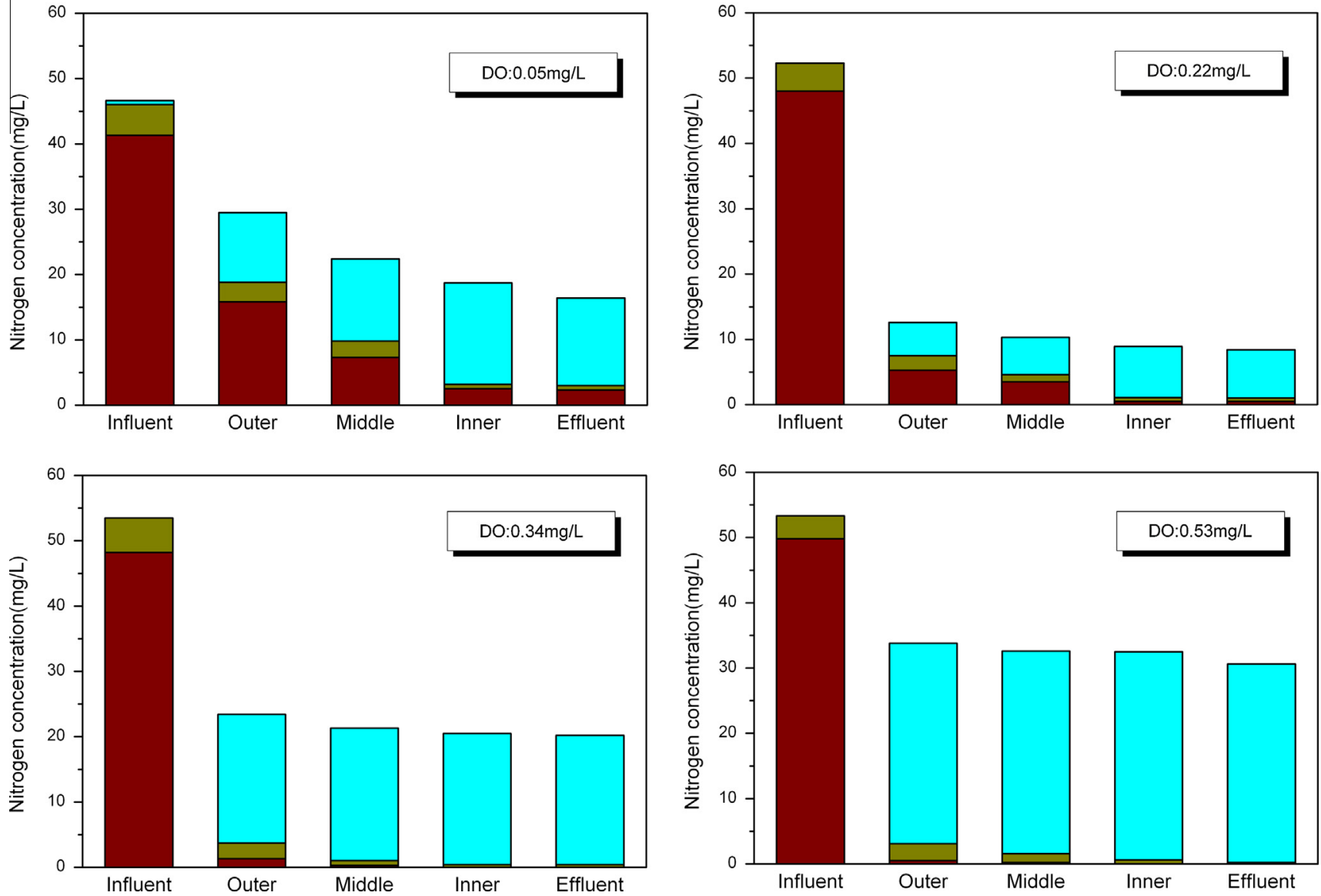

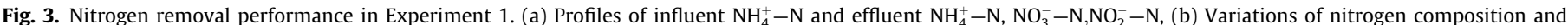
concentration along the Orbal system.

\subsection{PCR-DGGE analysis}

The isolation of total DNA was accomplished with DNA Autoplate (TanBead, Taiwan) by Automatic Plateform for Magnetic System-16 (TanBead, Taiwan) and DNA bands were observed by $1.0 \%$ agarose gel electrophoresis. F357GC (5'-CGCCCGCCGCGCGCGGCGG GCGGGGCGGGGGCACGGGGGGCCTACGGGAGGCAGCAG-3') and
R518 (5'-ATTACCGCGGCTGCTGG-3') were used to amplify the segment of eubacterial 16S rDNA. The PCR amplification reaction was performed using an MJ Research PTC-200 Peltier Thermal Cycler (Bio-Rad, USA) at a final volume of $50 \mu$ l. The reaction mixture contained $20 \mathrm{pmol}$ of both primers, $20 \mu \mathrm{mol}$ of each dNTPs, $5 \mu \mathrm{l}$ of $10 \times$ buffer (TaKaRa, Dalian, China), and 1.25 units of Taq DNA polymerase (TaKaRa, Dalian, China). The temperature cycling 
conditions were $94{ }^{\circ} \mathrm{C}$ for $3 \mathrm{~min}$, followed by 31 cycles of $94{ }^{\circ} \mathrm{C}$ for $30 \mathrm{~s}, 55^{\circ} \mathrm{C}$ for $30 \mathrm{~s}$, and $72{ }^{\circ} \mathrm{C}$ for $1 \mathrm{~min}$. A final extension at $72{ }^{\circ} \mathrm{C}$ for $10 \mathrm{~min}$ was used. The PCR product generated from each sample was separated on an $8 \%$ acrylamide gel with a linear denaturant gradient increasing from $30 \%$ to $60 \%$ using the Bio-Rad D-GENE System (Bio-Rad, USA). The DGGE was performed using $30 \mu \mathrm{l}$ of the PCR product in $1 \times \mathrm{TAE}$ buffer at $60^{\circ} \mathrm{C}$ and $70 \mathrm{~V}$ for $960 \mathrm{~min}$. The resulting gel was visualized with Gel Red (Biotium USA). The digital images were captured by a Fluor-S Multilmager (Bio-Rad, USA) and analyzed with Quantity One Software (Bio-Rad, USA).

\section{Results and discussion}

\subsection{Nitrogen removal performance in Experiment 1}

Fig. 3a depicts nitrogen profiles in the influent and effluent and nitrogen removal efficiency in the pilot Orbal oxidation ditch without internal recycle. Although the influent $\mathrm{NH}_{4}^{+}-\mathrm{N}$ concentration varied from $35.7 \mathrm{mg} / \mathrm{L}$ to $61.9 \mathrm{mg} / \mathrm{L}$, steadily low effluent $\mathrm{NH}_{4}^{+}-\mathrm{N}$ concentration with less than $2 \mathrm{mg} / \mathrm{L}$ on average and over $97 \%$ ammonia nitrogen removal efficiencies were obtained implying complete nitrification performed in the system during the whole experimental periods regardless of oxygen levels within the outer channel. However, TN removal performances were considerably varying among four operational runs compared with consistently high ammonia removal. Maximum nitrogen removal occurred at DO of about $0.20 \mathrm{mg} / \mathrm{L}$ with about $82 \% \mathrm{TN}$ removal efficiency averagely (Run 2), while 64\% and 59\% TN removals were obtained at Runs 1 and 4, respectively, while at Run 3 only 42\% TN were removed. It was indicated that TN removal efficiency closely depended on oxygen levels within the outer channel.

To further clarify the differences in TN removal performances, nitrogen compositions and concentrations along the triple-channel oxidation ditch under different DO conditions within the outer channel were analyzed (in Fig. 3b). As the figure shown, ammonia nitrogen generally accounted for about $80-85 \%$ of the total nitrogen in the influent and the rest represented organic nitrogen and oxidized nitrogen. At extremely low DO of $0.05 \mathrm{mg} / \mathrm{L}$, the first channel just only removed partial influent $\mathrm{NH}_{4}^{+}-\mathrm{N}$ concentration and the remaining of $\mathrm{NH}_{4}^{+}-\mathrm{N}$ were gradually removed through aerobic nitrification within followed two aerated channels while almost complete $\mathrm{NH}_{4}^{+}-\mathrm{N}$ removal was able to be accomplished at above $0.2 \mathrm{mg} / \mathrm{L}$ DO within the outer channel. It was likely that full nitrification was successfully performed at rather low oxygen concentration due to longer HRT and SRT of the system [6,25], although nitrification rate at the low DO was much lower than its maximum value at DO of above $2 \mathrm{mg} / \mathrm{L}$. As $\mathrm{NH}_{4}^{+}-\mathrm{N}$ and organic nitrogen were quite low and nitrites were hardly detected in the effluent, $\mathrm{NO}_{3}^{-}-\mathrm{N}$ was the main form of nitrogen in the effluent (in Fig. 3a and b) due to complete nitrification at long HRT and SRT. Therefore, TN removal in Orbal oxidation ditch strongly relied on denitrification efficiency of nitrates entirely occurred in the aerated-anoxic channel while ammonification and nitrification were enhanced in the highly aerated channels.

Table 4 summarizes the rates of nitrification and denitrification and SND efficiencies under different DO conditions during the Experiment 1. It was observed that nitrification rates obviously increased while denitrification rates firstly rose and then declined with increased DO within the outer channel implying the great impact of DO on the SND efficiency. At DO of about $0.2 \mathrm{mg} / \mathrm{L}$, nearly equally high rates of nitrification and denitrification led to an optimal SND efficiency of over 65\%, whereas, decreased SND efficiencies were caused by either low nitrification rate at extremely low DO or low denitrification rate at quite high DO in the outer chan-
Table 4

Rates of nitrification and denitrification and SND efficiencies in Experiment 1.

\begin{tabular}{lcccc}
\hline Average DO $(\mathrm{mg} / \mathrm{L})$ & 0.06 & 0.20 & 0.52 & 0.36 \\
\hline$r_{n}\left(\mathrm{mg} \mathrm{NH}_{4}^{+}-\mathrm{N} \cdot \mathrm{L}^{-1} / \mathrm{h}\right)$ & 2.53 & 4.77 & 6.24 & 5.1 \\
$r_{\text {den }}\left(\mathrm{mg} \mathrm{NO}_{3}^{-}-\mathrm{N} \mathrm{L}^{-1} / \mathrm{h}\right)$ & 1.58 & 3.18 & 1.17 & 2.06 \\
Average $\mathrm{SND}_{\text {eff }}(\%)$ & 39.5 & 66.7 & 18.8 & 40.4 \\
\hline
\end{tabular}

nel. Thus, TN removal in Orbal process mainly based on the degree of SND in outer channel $[9,10,20]$.

Online monitoring of DO and ORP have been proved to be practical and effective indicators for SND control in nitrogen removal process [26-28]. In this study, on-line ORP measurement for SND optimization in the outer channel was also implemented due to its strong correlation with DO and wider range for process control under very low oxygen condition [26]. Unlike low ORP ranged from $-100 \mathrm{mv}$ to $-50 \mathrm{mv}$ in non-aerated anoxic zones in $\mathrm{A} / \mathrm{O}$ process $[29,30]$, ORP value of $-50 \mathrm{mv}$ to $50 \mathrm{mv}$ under the aerated-anoxic condition was higher due to the presences of micro-aeration and oxidized nitrogen. The optimal ORP for SND seemed within the range of $10-40 \mathrm{mv}$ at about $0.2 \mathrm{mg} / \mathrm{L} \mathrm{DO}$ in this study.

\subsection{DO concentrations between the outer and middle channels in Experiment 2}

Table 5 shows DO concentrations between the outer and middle channels at different internal recycle ratios on the condition of the same total oxygen inputs. It was found that great DO stratification existed between two channels without internal recycle. With an increase of internal recycle in the modified Orbal system, DO in the outer channel rose while gradually declined in the middle channel if aeration supply were kept unchanged. DO differences between both channels became decreased even disappeared at high recirculation flow due to mixing of more high-oxygen liquor returned from the second channel. According to Experiment 1 results, DO should be kept around $0.2 \mathrm{mg} / \mathrm{L}$ for optimum TN removal through reducing rotating speeds of the aerated brush in the outer channel.

\subsection{Nitrogen removal performance in Experiment 2}

Fig. 4a shows the profiles of influent $\mathrm{NH}_{4}^{+}-\mathrm{N}$ and effluent $\mathrm{NH}_{4}^{+}-\mathrm{N}, \mathrm{NO}_{3}^{-}-\mathrm{N}, \mathrm{NO}_{2}^{-}-\mathrm{N}$. Rather low $\mathrm{NH}_{4}^{+}-\mathrm{N}$ concentration in the effluent (low than $1.0 \mathrm{mg} / \mathrm{L}$ ) was obtained during the whole experiment indicating that $0.2 \mathrm{mg} / \mathrm{L}$ DO was enough for nitrifiers to remove ammonia whether nitrate recycle was added or not. Besides, compared with Experiment 1, a slight drop of TN removal in Experiment 2 during two experiments was also found perhaps due to lower $\mathrm{C} / \mathrm{N}$ ratio in the modified oxidation ditch system with zero recycle ratio (see Table 1). Yet, it was more surprising that profile of effluent $\mathrm{NO}_{3}^{-}-\mathrm{N}$ experienced a rise firstly and then fall along with increased internal recycle. The similar changing tendency in TN removal (in Fig. 4b) was greatly influenced by nitrates reduction. The experimental results showed TN removal efficiencies at recycle ratios of 4.1 and 9.4 at Runs 2 and 3 were improved by about $6 \%$ and $11 \%$, respectively, in contrast with zero recycle at Run 1. This observation concluded that more $\mathrm{NO}_{3}^{-}-\mathrm{N}$ from the middle channel by means of recirculation was utilized as electron acceptors to promote pre-denitrification in the aerated-anoxic

Table 5

DO concentrations between the outer and the middle channels under the constant oxygen input in Experiment 2.

\begin{tabular}{llllll}
\hline Runs & Run 1 & Run 2 & Run 3 & Run 4 & Run 5 \\
\hline DO in outer channel $(\mathrm{mg} / \mathrm{L})$ & 0.21 & 0.28 & 0.35 & 0.46 & 0.53 \\
DO in middle channel $(\mathrm{mg} / \mathrm{L})$ & 1.12 & 0.97 & 0.82 & 0.75 & 0.62 \\
\hline
\end{tabular}



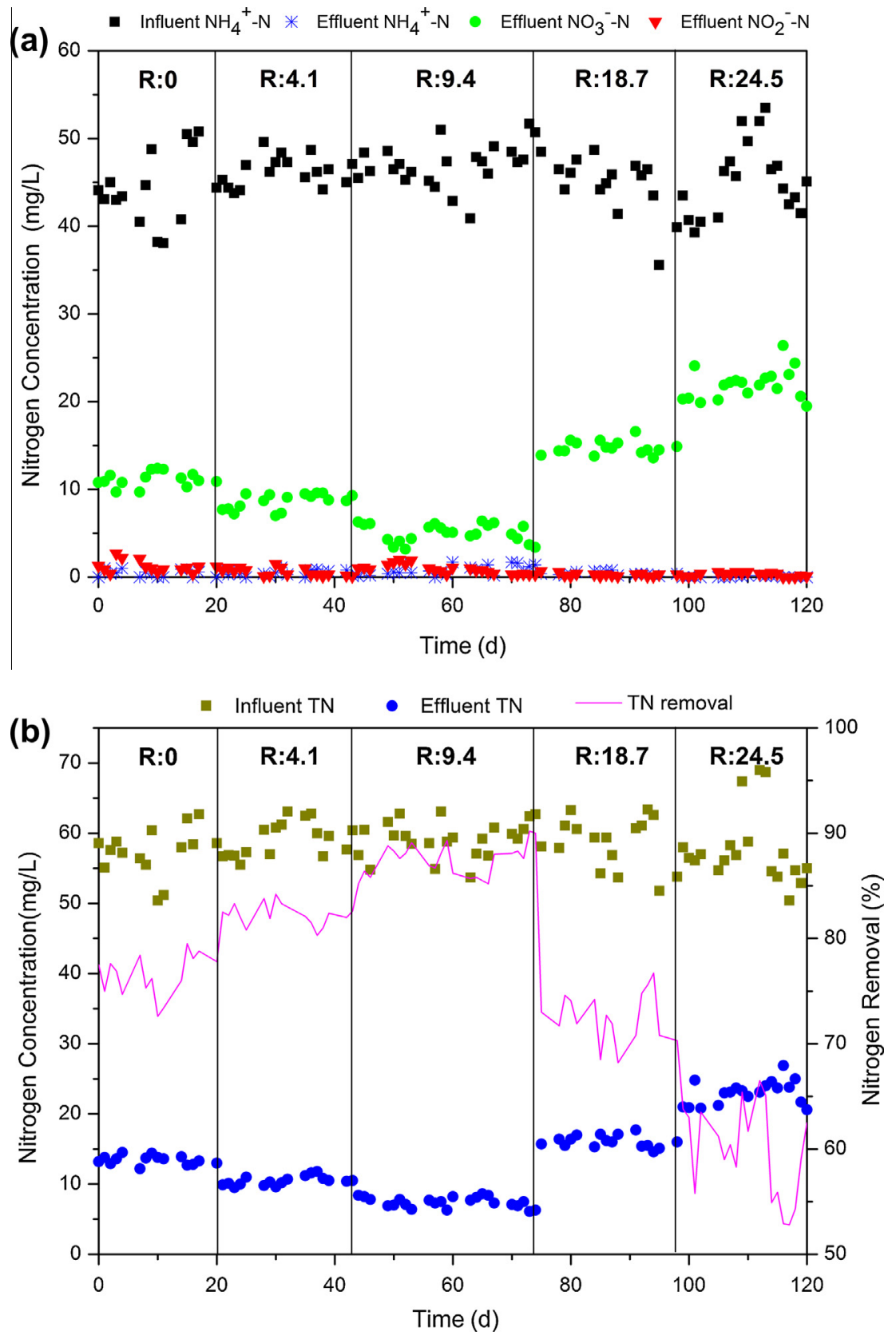

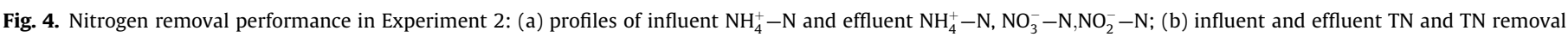
efficiency.

outer channel. When the ratio was controlled at 9.4, excellent TN removal efficiency as high as $87 \%$ with effluent TN $<8 \mathrm{mg} / \mathrm{L}$ was acquired. But TN removal performance began to sharply decrease at excessively high recycle ratio of above 10 (Runs 4 and 5). The possible explanation for this was less carbon source for denitrification in the outer channel and more organic matters were used for aerobic degradation rather than for anoxic denitrification due to significantly frequent alternation of the mixed liquor between anoxic and oxic conditions within two channels with further excessively increase in internal recycle ratio. Furthermore, strong diluted effect of the returned liquor on carbon source and high nitrates loading induced by high recycle flow gave rise to insufficient $\mathrm{C} / \mathrm{N}$ ratios for denitrification, resulting in poor TN removal. Consequently, the suitable control of internal recycle in the modified oxidation ditch system allowed for improved nitrogen removal and reduced oxygen consumption simultaneously.

\subsection{Nitrogen mass balances with and without nitrate recycle}

Nitrogen elimination in the biological treatment process was mainly attributed to three pathways: ammonia stripping, assimilation, nitrification-denitrification. In the nitrogen balance, ammonia stripping was assumed to be negligible as the $\mathrm{pH}$ of the mixed liquor in the ditch was below 7.5 [3]. Nitrogen loss in biomass assimilation through sludge wasting $\left(R_{\text {waste }}\right)$ can be estimated by the Ref. [22].

$R_{\text {waste }}(\mathrm{mgN} / \mathrm{d})=Q_{\text {was }} \times X_{\text {vss }} \times i_{\text {vss }}$

where $Q_{\text {was }}$ is the sludge wasting rate; $X_{v s s}$ is the waste sludge MLVSS and $i_{v s s}$ represents the nitrogen content by weight of the MLVSS, 7.5\% [31].

Nitrogen mass balances in Fig. 5 were compared at recycle ratios of 0 (Day 3) and 9.4 (Day 56) under identical process 


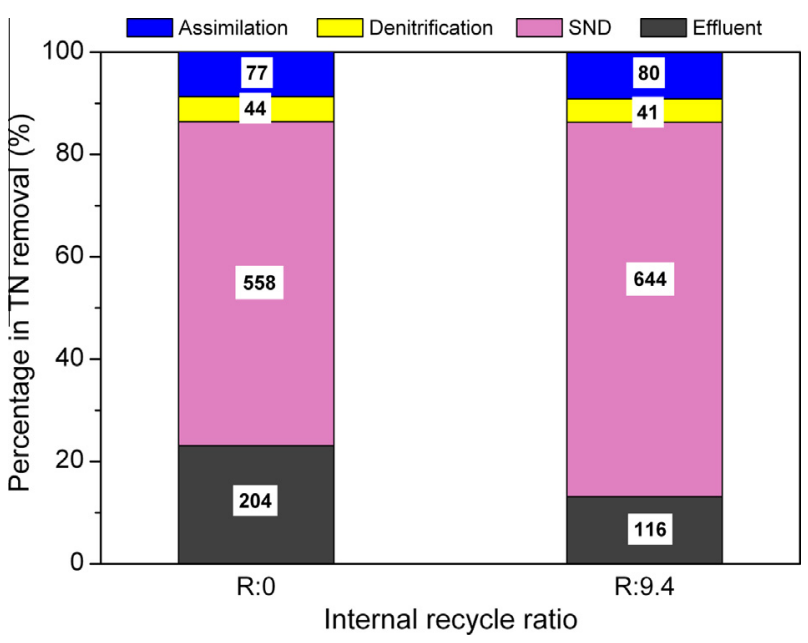

Fig. 5. Nitrogen mass balances in the Orbal system at recycle ratios of 0 and 9.4 (figure labels indicate gTN/d).

parameters such as HRT, SRT and influent TN load in Experiment 2. As revealed in the figure, TN in the effluent occupied $23.1 \%$ and $13.1 \%$ of influent TN (about $880 \mathrm{gTN} / \mathrm{d}$ ) at the ratios of 0 and 9.4 , respectively. The average $9 \%$ of the influent TN was removed via assimilation in form of wasted sludge at both ratios. Therefore, denitrification seemed the dominant mechanism of TN removal in the multi-channel process. The great majority of the influent TN was removed via SND in the outer channel, while only a small proportion of about $5 \%$ was removed within aerobic channels and final settler. Compared with $63.3 \%$ of the influent TN via SND removal without recycle, TN removal was further increased by about $10 \%$ at the optimal recycle ratio of 9.4 , which strongly implied that pre-denitrification was responsible for TN improvement in the aerated-anoxic system with internal nitrate recycle.

\subsection{Variations in microbial community}

In this study, the bacteria of different sludge samples from the outer, middle and inner channel of the Orbal oxidation ditch, respectively in Experiment 1 were analyzed by PCR-DGGE to link the relationship between nitrogen removal performance and bacterial community characteristics. As shown in Fig. 6, La, Lb and Lc (Run 1); Ld, Le and Lf (Run 2); Lg, Lh and Li (Run 3) represented DGGE profiles of different sludge samples from the outer middle and inner channel of Orbal oxidation ditch, respectively. The number of DGGE bands shows the relative diversity of the bacterial community [32] and the intensity of the specific band represents the relative abundance of the corresponding microbial species [33]. The appearance or disappearance of bands indicates changes in the bacterial community [34].

The dominant microbial population (Band 22) and other mutual populations (e.g. Bands 7, 11, 19 and 20) were commonly found among all lanes by DGGE fingerprints indicating that these bacterial groups were slightly affected by influent wastewater characteristics and operational conditions during the whole experiment.

Fig. 6 also demonstrated similar band patterns under the same operating period while band profiles varied largely among different three runs indicating changes in microbial community mainly associated with operational adjustment rather than spatial distribution of the bio-system. The biodiversities in microbial community at Run 3 were lower than Runs 1 and 2 due to disappearances of several bands (Bands 13-18), despite some differences in bacterial composition at both runs. A few heterotrophic bacteria such as denitrifiers in the outer channel (Lane g) might be inhibited by relatively high oxygen concentration resulting in poor denitrification. For Runs 1 and 2, less similarity in bands pattern between La and Ld from the outer channel, although both had abundant bands. It was more likely that the number and activity of nitrifying bacteria at Run 1 would be greatly decreased owing to extreme absence of oxygen, leading to partial $\mathrm{NH}_{4}^{+}-\mathrm{N}$ removal. With increased aeration supply for the outer channel, intensities of some bands (i.e. Bands 11, 13 and 30) at Run 2 were enhanced indicating that certain functional bacterial populations such as some nitrifying bacteria adapted to low-oxygen environment [35] might be gradually enriched. These bacteria were capable of participating SND within the aerated-anoxic channel in the presence of heterotrophic denitrifying bacteria. As for two other channels, microbial diversities became gradually lower at Runs 2 and 3 while somewhat higher at Run 1, possibly dependent on the quantity of substrates (organic matter and nitrogen) and their uptake rates in the first channel.

These observations implied that variations in microbial diversity and population constitution under different DO conditions
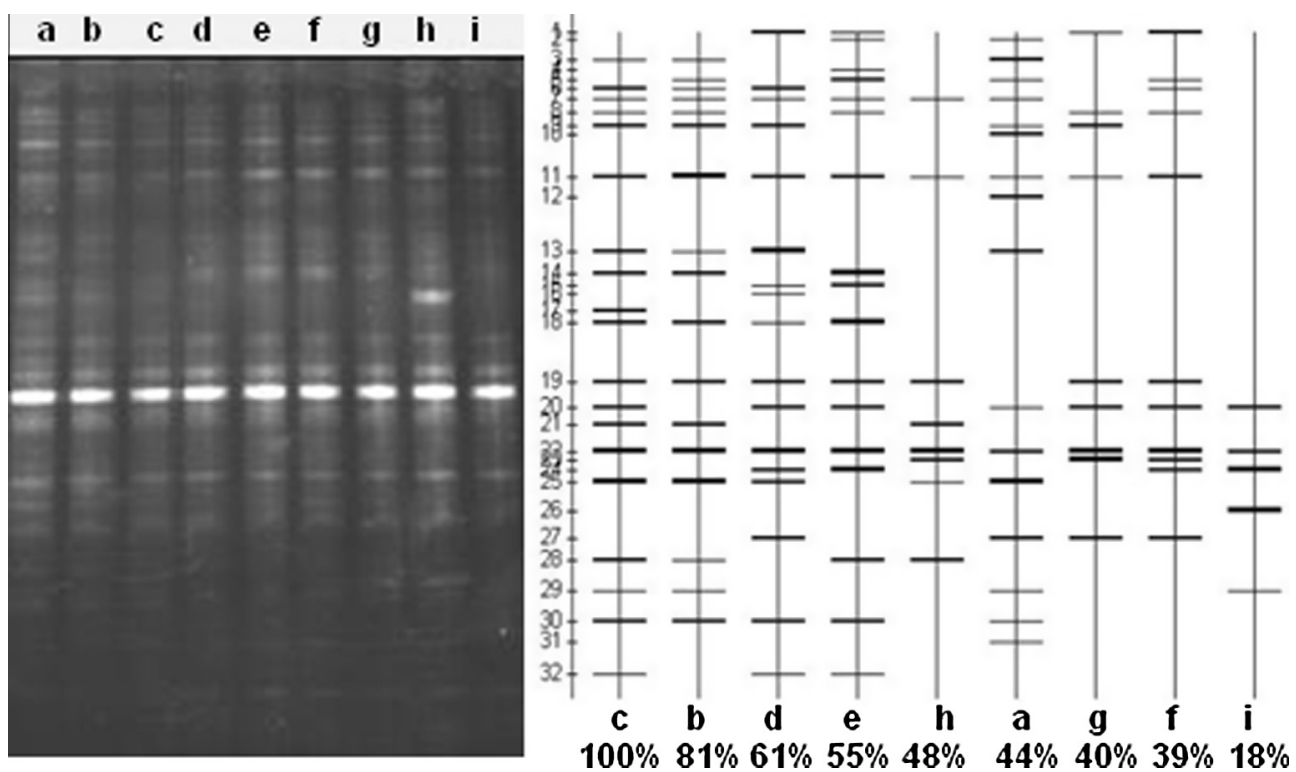

Fig. 6. DGGE profiles of sludge samples from different channels in the Orbal system under different Do conditions (percentages indicate a coefficient similar). 
within the outer channel seemed to be responsible for differences in TN removal efficiency of the oxidation ditch system, although specific bacterial identification and quantitative analysis were not conducted.

\section{Conclusions}

Maximum TN removal efficiency was achieved through accurate control of DO $(0.15-0.25 \mathrm{mg} / \mathrm{L})$ within the outer channel in a pilot-scale modified Orbal oxidation ditch with nitrate recycle. TN removal efficiency was further increased to about $87 \%$ at the optimal recycle ratio of 9.4 for improved denitrification. Nitrogen mass balances indicated nitrogen removal was enhanced via the coupling of SND and pre-denitrification under the aerated-anoxic condition within the outer channel. Variations in microbial community by PCR-DGGE under different DO conditions in the outer channel might lead to differences in TN removal performance.

\section{Acknowledgements}

The authors thank Dr. David Howard for the English revision of this manuscript. This work was financially supported by the Qualified Personnel Foundation of Taiyuan University of Technology (QPFT) (No. tyut-rc201262a) and the National Key Technology R\&D Program of China (No. 2006BAC19B02).

\section{References}

[1] H.D. Stensel, T.E. Coleman, W.E.R. Foundation, Technology assessments: nitrogen removal using oxidation ditches, Water Environ. Res. Found., 2000.

[2] J. Liu, J. Van Groenestijn, H. Doddema, B. Wang, Influence of the aeration brush on nitrogen removal in the oxidation ditch, Eur. Water Pollut. Control 6 (1996) 25-30.

[3] X. Hao, H.J. Doddema, J.W. van Groenestijn, Conditions and mechanisms affecting simultaneous nitrification and denitrification in a Pasveer oxidation ditch, Bioresour. Technol. 59 (1997) 207-215

[4] US EPA, Wastewater Technology Fact Sheet: Oxidation Ditches, Office of Water Washington, D.C., EPA 832-F-00-013, 2000.

[5] R. Drews, W. Malan, P. Meiring, B. Moffatt, The Orbal extended aeration activated sludge plant, J. Water Pollut. Control Fed. (1972) 221-231.

[6] B.E. Rittmann, W.E. Langeland, Simultaneous denitrification with nitrification in single-channel oxidation ditches, J. Water Pollut. Control Fed. (1985) 300308.

[7] USFilter/Envirex, The Orbal System for Biological Treatment, <http:// www.usfilter.com/water>, 2002.

[8] M. O’Neill, N.J. Horan, Achieving simultaneous nitrification and denitrification of wastewaters at reduced cost, Water Sci. Technol. 32 (1995) 303-312.

[9] X. Zhou, X. Guo, Y. Han, J. Liu, J. Ren, Y. Wang, Y. Guo, Enhancing nitrogen removal in an Orbal oxidation ditch by optimization of oxygen supply: practice in a full-scale municipal wastewater treatment plant, Bioproc. Biosyst. Eng. 35 (2012) 1097-1105.

[10] G.T. Daigger, H.X. Littleton, Characterization of simultaneous nutrient remova in staged, closed-loop bioreactors, Water Environ. Res. 72 (2000) 330-339.

[11] H.D. Park, J.M. Regan, D.R. Noguera, Molecular analysis of ammonia-oxidizing bacterial populations in aerated-anoxic Orbal processes, Water Sci. Technol. 46 (2002) 273-280.

[12] K. Pochana, J. Keller, Study of factors affecting simultaneous nitrification and denitrification (SND), Water Sci. Technol. 39 (1999) 61-68.
[13] R.J. Zeng, R. Lemaire, Z. Yuan, J. Keller, Simultaneous nitrification, denitrification, and phosphorus removal in a lab-scale sequencing batch reactor, Biotechnol. Bioeng. 84 (2003) 170-178.

[14] H. Satoh, Y. Nakamura, H. Ono, S. Okabe, Effect of oxygen concentration on nitrification and denitrification in single activated sludge flocs, Biotechnol. Bioeng. 83 (2003) 604-607.

[15] G. Insel, N. Artan, D. Orhon, Effect of aeration on nutrient removal performance of oxidation ditch systems, Environ. Eng. Sci. 22 (2005) 802-815.

[16] Y. Liu, H. Shi, L. Xia, H. Shi, T. Shen, Z. Wang, G. Wang, Y. Wang, Study of operational conditions of simultaneous nitrification and denitrification in a Carrousel oxidation ditch for domestic wastewater treatment, Bioresour. Technol. 101 (2010) 901-906.

[17] Y.-C. Chiu, L.-L. Lee, C.-N. Chang, A.C. Chao, Control of carbon and ammonium ratio for simultaneous nitrification and denitrification in a sequencing batch bioreactor, Int. Biodeter. Biodegr. 59 (2007) 1-7.

[18] K.A. Third, B. Gibbs, M. Newland, R. Cord-Ruwisch, Long-term aeration management for improved N-removal via SND in a sequencing batch reactor, Water Res. 39 (2005) 3523-3530.

[19] G. Insel, D. Russell, B. Beck, P.A. Vanrolleghem, Evaluation of nutrient removal performance for an ORBAL plant using the ASM2d model, Proc. Water Environ. Fed. (2003) 263-279

[20] S. Gao, Y. Peng, S. Wang, J. Yan, Novel strategy of nitrogen removal from domestic wastewater using pilot Orbal oxidation ditch, J. Environ. Sci. 18 (2006) 833-839.

[21] J. Baeza, D. Gabriel, J. Lafuente, Effect of internal recycle on the nitrogen removal efficiency of an anaerobic/anoxic/oxic $\left(\mathrm{A}^{2} / \mathrm{O}\right)$ wastewater treatment plant (WWTP), Process Biochem. 39 (2004) 1615-1624.

[22] T.W. Tan, H.Y. Ng, Influence of mixed liquor recycle ratio and dissolved oxygen on performance of pre-denitrification submerged membrane bioreactors, Water Res. 42 (2008) 1122-1132.

[23] APHA, Standard Methods For The Examination Of Water And Wastewater, American Public Health Association, Washington, DC, 1998.

[24] J. Carrera, J.A. Baeza, T. Vicent, J. Lafuente, Biological nitrogen removal of highstrength ammonium industrial wastewater with two-sludge system, Water Res. 37 (2003) 4211-4221.

[25] E.V. Munch, P. Lant, J. Keller, Simultaneous nitrification and denitrification in bench-scale sequencing batch reactors, Water Res. 30 (1996) 277-284.

[26] M. Fuerhacker, H. Bauer, R. Ellinger, U. Sree, H. Schmid, F. Zibuschka, H. Puxbaum, Approach for a novel control strategy for simultaneous nitrification/ denitrification in activated sludge reactors, Water Res. 34 (2000) 2499-2506.

[27] N. Weissenbacher, C. Loderer, K. Lenz, S.N. Mahnik, B. Wett, M. Fuerhacker, $\mathrm{NO}_{x}$ monitoring of a simultaneous nitrifying-denitrifying (SND) activated sludge plant at different oxidation reduction potentials, Water Res. 41 (2007) 397405.

[28] J.B. Holman, D.G. Wareham, COD, ammonia and dissolved oxygen time profiles in the simultaneous nitrification/denitrification process, Biochem. Eng. J. 22 (2005) 125-133.

[29] X. Wang, Y. Peng, Y. Ma, S. Wang, Effects of operational variables on nitrogen removal performances and its control in a pre-denitrification plant, Chem. Eng. Technol. 30 (2007) 234-241.

[30] Y. Peng, Y. Ma, S. Wang, Improving nitrogen removal using on-line sensors in the A/O process, Biochem. Eng. J. 31 (2006) 48-55.

[31] S. Yang, F. Yang, Z. Fu, R. Lei, Comparison between a moving bed membrane bioreactor and a conventional membrane bioreactor on organic carbon and nitrogen removal, Bioresour. Technol. 100 (2009) 2369-2374.

[32] G. Muyzer, K. Smalla, Application of denaturing gradient gel electrophoresis (DGGE) and temperature gradient gel electrophoresis (TGGE) in microbial ecology, Anton. Van Leeuwenhoek 73 (1998) 127-141.

[33] H.H.P. Fang, H. Liu, Effect of pH on hydrogen production from glucose by a mixed culture, Bioresour. Technol. 82 (2002) 87-93.

[34] Y.C. Chung, Evaluation of gas removal and bacterial community diversity in a biofilter developed to treat composting exhaust gases, J. Hazard Mater. 144 (2007) 377-385.

[35] H.D. Park, D.R. Noguera, Evaluating the effect of dissolved oxygen on ammonia-oxidizing bacterial communities in activated sludge, Water Res. 38 (2004) 3275-3286. 